\title{
Making the health system work by and for Indigenous women in Guatemala: a community led multisectoral collaboration
}

\author{
Claudia Nieves Velásquez and colleagues report how a community led national alliance of \\ Indigenous women's organisations is working to improve the delivery of healthcare for Indigenous \\ women through collaboration with other community based organisations, government (health and \\ ombudsman), and international partners
}

I nequities in indigenous peoples' health persist, reflecting the continued disadvantage and discriminatory attitudes experienced by indigenous people worldwide that affect their use of health services. ${ }^{12}$ For Guatemala, where nearly half of the population is indigenous-mainly Mayan groups-inequities remain a persistent challenge. Most of the country's Indigenous peoples have higher rates of poverty and were profoundly affected by the civil war (1960-96), with about $83 \%$ of the two million victims belonging to one of the Mayan Indigenous groups. ${ }^{13-6}$ The Alianza Nacional de

\section{KEY MESSAGES}

- ALIANMISAR monitors a range of public health services, in collaboration with other community based organisations, the Ministry of Health, the Ombudsman for Human Rights, and international partners, to generate evidence for improvements to the quality and cultural acceptability of health services for Indigenous women

- Previous work by Indigenous women as advocates in their own communities aided collaboration with ALIANMISAR, bringing additional technical and financial resources to enable further advocacy

- ALIANMISAR's methods and its presence in the political space for many years makes it a legitimate, credible, and trustworthy partner, facilitating of health and other sectors to respond to its advocacy claims

- A strategic review is needed to determine how to fund and structure ALIANMISAR in future to build on existing gains in a sustainable and equitable way
Organizaciones de Mujeres Indigenas por la Salud Reproductiva Nutrición y Educación (National Alliance of Indigenous Women's Organizations for Reproductive Health, Nutrition, and Education, ALIANMISAR) is one example of how Guatemala's Indigenous communities are working to deal with these challenges. ALIANMISAR's efforts built on the 1996 Peace Accords, which marked the end of the civil war and emphasised the need for civil society stewardship and active involvement in governance. ${ }^{7}$ The accords also mandated a 50\% increase in the public health budget, focused on preventing ill health, decreasing maternal and infant mortality, and eradicating polio and measles.

ALIANMISAR is a network led by Indigenous women and was formed in 2006 to improve the quality and cultural acceptability of healthcare provided to Indigenous women. ${ }^{5}$ As part of its mission, ALIANMISAR monitors a range of public health services at national, departmental, and municipal levels, in collaboration with other community based organisations, the executive and legislative sectors of the government (the Ministry of Health and the Ombudsman for Human Rights), and international partners (see suppl 1 on bmj.com). Monitoring of health services by ALIANMISAR volunteers and staff from the ombudsman's field offices includes interviews with service providers and users and an inspection of the facilities, equipment, supplies and medicines. To date, joint monitoring has contributed to important improvements in health policy and legislation, health services, and infrastructure for Indigenous women.

We focus on the factors that have enabled this multisectoral collaboration; impetus for this analysis comes from recognition that multisectoral collaboration is essential to achieve the sustainable development goals. ${ }^{8}$

\section{Why was monitoring needed?}

After more than a decade of post-war reconstruction, inequities in the levels of maternal mortality between Indigenous and non-indigenous women remained striking, indicating that the health system was not meeting the needs of Indigenous women (box 1). ${ }^{9}$

Service user monitoring generates knowledge and evidence that can be used to advocate for change and improvements. When combined with information on health provider performance and user entitlements, monitoring has been found to lead to better quality and more frequently utilised health services, and ultimately improved health outcomes. ${ }^{16}$ Monitoring by health service users is also an integral part of ensuring the state's accountability for realising the health and human rights of Indigenous people ${ }^{17}$. Monitoring by Indigenous women is therefore key to ensuring the availability, physical and financial accessibility, cultural appropriateness, and quality of health and care services. Since 2008 ALIANMISAR, together with Ministry of Health authorities, has advocated for improved quality, availability, and accessibility of culturally appropriate health services (box 2).

\section{Joint monitoring by ALIANMISAR and other sectors}

ALIANMISAR began monitoring health services for Indigenous women in collaboration with the field offices of the Office of the Human Rights Ombudsman (box 3) in 2010. This was achieved through creation of local networks (REDMISAR; Network of Indigenous women's organisations for Reproductive Health, Nutrition and Education) and after receipt of technical and funding support from the USAID funded Health and Education Policy Project (HEP+). Monitoring is used to gather evidence about both 
Box 1: Inequities in Indigenous maternal mortality

In 2000, the maternal mortality ratio for Indigenous women in Guatemala was more than three times that of non-Indigenous women (211 and 70 maternal deaths per 100000 live births respectively, and an absolute number of 653 maternal deaths overall). This difference fell to 2.1 times that of non-indigenous women in 2007 (163 and 78 maternal deaths per 100000 live births respectively, and 537 maternal deaths overall), and to 1.75 times by 2015 (139 and 79 maternal deaths per 100000 live births respectively, and 436 deaths overall). ${ }^{10-12}$ One study found that a large portion of ethnic differences in the use of institutional delivery services between Indigenous and non-indigenous women was attributable to Indigenous women not speaking Spanish. ${ }^{13}$ This study and a 2015 health systems assessment for Guatemala ${ }^{14}$ indicate challenges with availability (eg, no qualified health staff at the clinic), accessibility (eg, clinic too far), acceptability (eg, "we cannot give birth the way we want to"), and quality (eg, clinic staff impolite or don't speak the local language) of services. The findings are also consistent with global evidence on Indigenous women's use of maternal health services and health outcomes, whereby recommended action by countries includes tackling discrimination; making health centres physically, financially, and culturally accessible; and ensuring equal access to health services. ${ }^{15}$

problems and improvements. Other permanent stakeholders in the monitoring process include the Indigenous men's network REDHOSEN (Men's network for Health, Education and Nutrition), municipal government (eg, mayors), and the Ministry of Health (supplementary files 1 and 2).

ALIANMISAR has developed over time with regard to its main collaborations and the public health topics monitored (fig 1). The range of topics monitored has increased, from reproductive health services in 2010 to include monitoring of nutrition services during the first 1000 days of life. These additions have been driven by political events, such as the health system crisis that led to a reduction in primary healthcare coverage in $2014 / 15$, a reduction in immunisation rates, ${ }^{1421}$ and the ongoing high rates of chronic malnutrition. For monitoring nutrition services, ALIANMISAR is an elected member of two other entities working on this issue: INCOPAS (the social participation body for food and nutrition

\section{Box 2: Culturally appropriate health services}

In Guatemala, current legislation defines culturally appropriate health services as those that are:

- Free of discrimination

- Provided bilingually in Spanish and the local Mayan language so the service is accessible to people who communicate in a language other than Spanish

- Focused on the population they serve, with a care model that integrates traditional and modern systems. ${ }^{18}$

A focus on the population served includes the development of norms, practices, and standards to ensure that health services are culturally appropriate and enable Indigenous women to deliver in the most comfortable position for them. For example, vertical birth (giving birth in an upright or squatting position) is a common cultural practice among Indigenous women in Guatemala. This also requires provider training in skills and techniques related to communication, health education, and community engagement to appropriately respond to and respect the culture of Indigenous people. ${ }^{19}$ Health services should also be designed, organised, and implemented in accordance with Indigenous peoples' values and way of life. tifying themselves and speaking the local language. ALIANMISAR has also used the results of monitoring to inform important civil society advocacy initiatives for the creation, approval, and implementation of norms, laws, and policies that guarantee access to high quality health services, emphasising cultural appropriateness, and that consider the health needs of Indigenous people (box 4).

We report an analysis aiming to establish the factors underlying ALIANMISAR's work which may have contributed to its success in collaborating with other sectors to improve provision of healthcare for Indigenous women in Guatemala. Findings come from a process of document review, key informant interviews, and dialogue with a range of stakeholders at national, departmental, and municipal levels (supplementary file 3).

\section{Enabling factors for collaboration}

We identified five different but complementary factors that enabled ALIANMISAR to successfully collaborate with other sectors and contributed to knowledge and evidence that was used to advocate for changes to health services and care for Indigenous women in Guatemala.

\section{Legislation and mechanisms for citizen participation}

Firstly, having existing legislation and mechanisms that required and supported citizen participation including monitoring has been key. Guatemala's constitution mandates civil society to hold government accountable, obliging the state to create processes and mechanisms for citizen participation in the governance of health and social sectors. ${ }^{2627}$ This includes participation in the planning, supervision, execution, and administration of health programmes that are key actions for guaranteeing the right to health. ${ }^{28}$ This meant that when ALIANMISAR was established there was no question about their right to participate in the governance of health services.

This legislative framework has opened the window for the advocacy work of civil society organizations in the protection and promotion of women's development, based on the obligation of the State to provide services and the application of sanctions for violations to its integrity and rights, which is the foundation of the [advocacy] work of ... ALIANMISAR (Andrea Santos, project coordinator, ALIANMISAR) ${ }^{29}$

As a signatory to the International Labour Organization 169 Agreement and the UN 


\section{Box 3: Office of the Human Rights Ombudsman, Guatemala}

The Office of the Human Rights Ombudsman was created by the National Assembly in 1985 and is responsible for monitoring public sector programmes and performance. The office operates under an agreement between the Office of the United Nations High Commissioner for Human Rights and the Government of Guatemala. ${ }^{20}$ The functions of the ombudsman are to monitor human rights in Guatemala, to provide technical assistance to the government, and to advise state institutions and civil society to enhance the promotion and protection of human rights.

Declaration on the Rights of Indigenous Peoples ${ }^{17}{ }^{30}$ the State of Guatemala is obliged to support the right of Indigenous people to participate in decisions that affect them, including development priorities. ALIANMISAR makes use of these mechanisms, including legal and public policy frameworks, to advocate for change and improvements in health services consistent with a human rights based approach to guaranteeing the right to health.

\section{Existing foundations and networks of ALIANMISAR}

Secondly, an existing group of advocates recognised by their Indigenous communities was already in place when ALIANMISAR began. Many Indigenous women who joined ALIANMISAR were already working as volunteers in their communities before its foundation. Most were recognised as credible advocates within their own communities and by other stakeholders. This meant that monitoring findings are seen as reliable with Indigenous communities, as well as with other stakeholders. ALIANMISAR volunteers brought a range of individual skills and experience, including working within the health system as community facilitators, midwives, and health promoters. Most volunteers speak their local Mayan language. Participation by Indigenous women speaking the local language is vital and gives other stakeholders (such as the ombudsman's office) confidence in the findings. ALIANMISAR's credibility was further bolstered by its commitment to ongoing follow-up on the results of monitoring to ensure the correct implementation of legislative and public policy mandates (box 4).

Health service stakeholders have also emphasised the value of ALIANMISAR's credibility for the collaborative work.

When they [the local network] present the findings from the monitoring, we take the opportunity to ask them to talk to community members about using the health services which are open to them, because ... communities know them: their members have credibility, and that also helps us to gain their trust (Health sector key informant)

Resourcing: technical and financial

Thirdly, donor funding of about \$160680 (£125 000; €140 000) annually since 2010 via the $\mathrm{HEP}+$ project has been critical to ALIANMISAR's work and existing HEP+ technical support. Funding has been used to pay for a national level technical secretary and an additional five technical facilitators to support networks at departmental and municipal levels, and to provide some funds to reimburse ALIANMISAR's volunteers for travel and related expenses when undertaking monitoring or advocacy activities. USAID funding covers 30 municipalities in departments prioritised by USAID for funding in Guatemala, not all municipalities where ALIANMISAR is active. ${ }^{331}$

Training and capacity building in human rights literacy, skills for negotiation, and advocacy with state authorities are important strategies for improving Indigenous people's participation and advocacy for their own interests. ${ }^{6}$ ALIANMISAR volunteers are trained in the topics/health issues covered by monitoring, as well as in human rights, monitoring, reporting, advocacy, and political dialogue. The HEP+ project coordinator provides training to the $\mathrm{HEP}+$ facilitators and

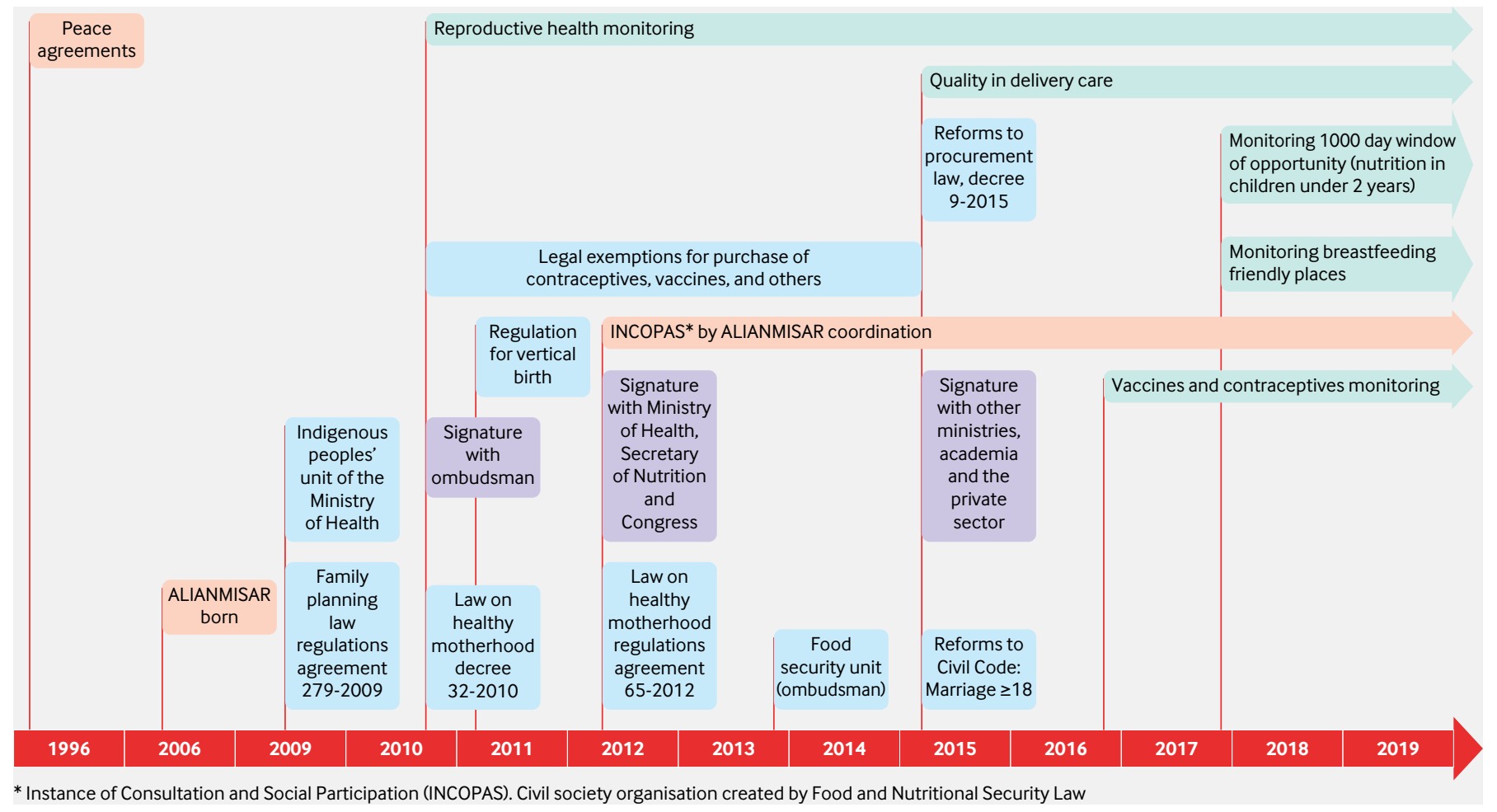

Fig 1 | Timeline of ALIANMISAR 


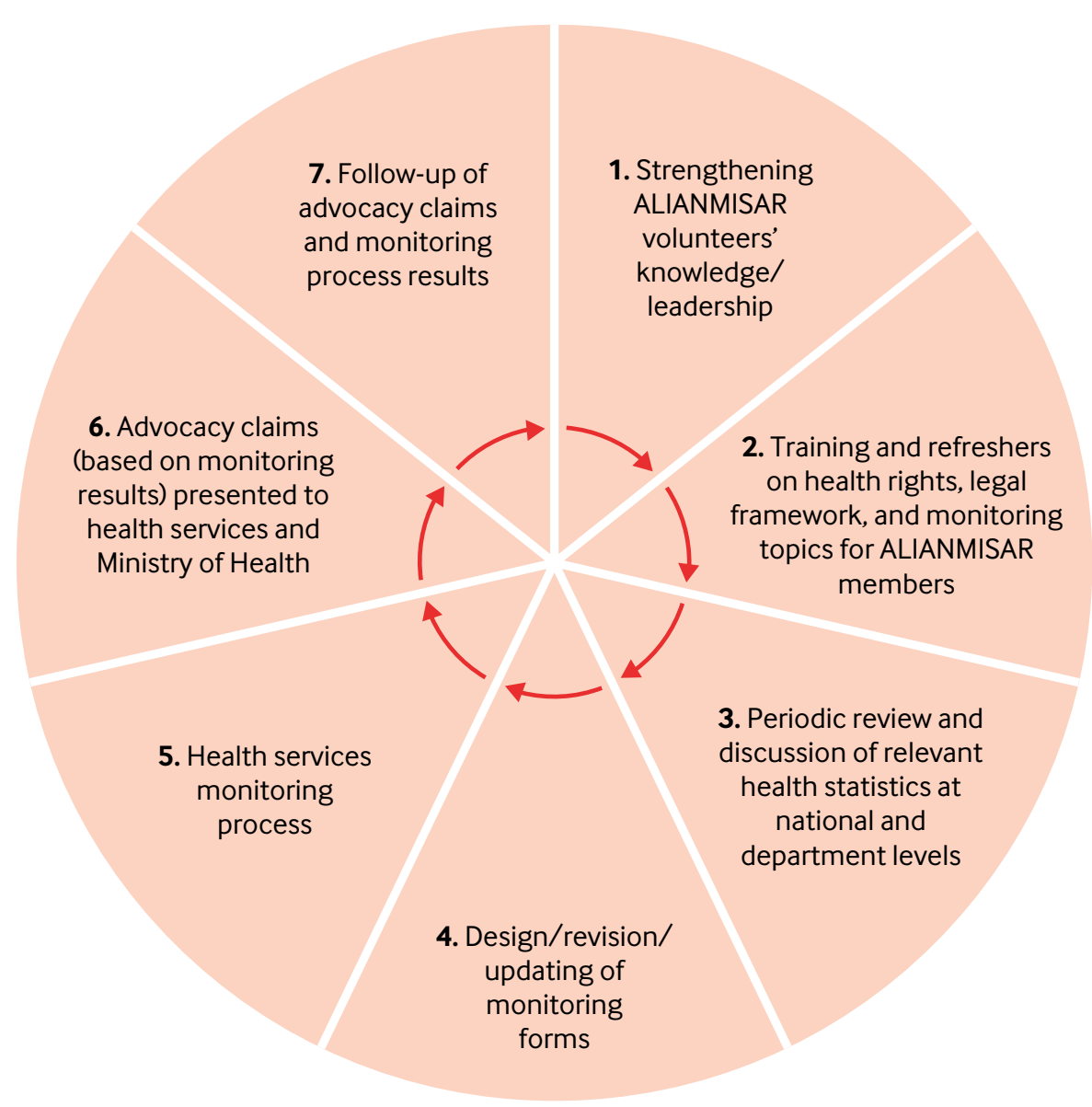

Fig 2 | ALIANMISAR's advocacy and political dialogue process sometimes directly to local network leaders. HEP+ department level technical facilitators assist in compiling, analysing, and presenting the results from monitoring, including prioritisation of findings and development of recommendations for inclusion in reports, presentations, and petitions.

Stakeholders described ALIANMISAR monitors as technically knowledgeable about health rights for Indigenous women and a credible source for other community led organisations, as well as effective advocates, experienced in dealing with the authorities and the media. ALIANMISAR monitors underlined the importance and value of training.

"The training has given me the tools and the confidence to exercise my role, and that has also facilitated successful monitoring" (ALIANMISAR key informant)

However, monitoring of health services by ALIANMISAR relies on Indigenous women working as volunteers. Reliance on volunteers was identified by some stakeholders as affecting the sustainability
Box 4: Examples of changes to health policy, legislation, services, and infrastructure linked with monitoring and advocacy by ALIANMISAR

- Creation of the Ministry of Health's Indigenous Peoples' Unit in 2009, which is responsible for designing and implementing programmes, policies, and norms to contribute to political and strategic conditions for the right to health of Indigenous people

- Enactment of the Healthy Motherhood Decree of the Congress of the Republic of Guatemala in 2010, aiming to improve the health and quality of life of women and newborns and to strengthen national family planning and reproductive health programmes ${ }^{25}$

- Restoration of the supply of basic drugs, micronutrients, and family planning materials to the health post at Lagunas Cuaches, San Juan Ostuncalco, in October 2012; all key for the provision of preventive health services ${ }^{24}$

- Establishment in March 2017 of a new maternity unit in the hospital in the municipality of Quetzaltenango. This enables pregnant women living in rural areas remote from health services to receive adequate and culturally relevant care before, during, and after delivery ${ }^{24}$ of ALIANMISAR, as volunteers often leave to take up paid employment. Some volunteers, however, noted that the training not only equipped them to undertake monitoring but also built skills that they could use to obtain and/or retain employment.

\section{Methods used for generating findings for change}

Fourthly, the strength of the findings produced and used by ALIANMISAR for advocacy is both an outcome of collaboration with partners, such as the ombudsman and $\mathrm{HEP}+$, and also one of the key enablers of collaboration with the health sector. Findings generated through monitoring fulfil several functions. They serve to identify potential for improvements in healthcare facilities, including service provision. For example, monitoring by ALIANMISAR in 2015 showed that culturally inappropriate practices such as washing women in cold water in health facilities are ongoing and contribute to Indigenous women's reticence to use those facilities to give birth. ${ }^{432}$

After my delivery, they woke me up at 3:00 in the morning so that I could bathe with cold water; they said that if I bathe the doctor would check me, but the doctor never came to check me (Health services user, Coban Hospital ${ }^{32}$ )

The findings also provide a strong foundation underpinning ALIANMISAR's advocacy for improvements to health policy, protocols, health services, and facilities, resulting in improvements in care (box 4). Consistent and systematic documentation including annual reporting, ${ }^{2233}$ together with the use of media such as photography to document poor conditions of health facilities, and combined with the participatory nature of the monitoring ${ }^{34}$ has been instrumental in persuading health and other stakeholders of the validity and reliability of ALIANMISAR's findings and the need for proposed changes.

It was from the evidence and results generated by the monitoring exercises, and with their attitude to work, that they gained credibility in the eyes of other actors and improved communications between the different participants in the monitoring process (Ombudsman KI)

Sharing the evidence has also improved Indigenous women's health and human rights literacy. ${ }^{6}$ Using monitoring to identify weaknesses and manage improvements in health services has increased communities' knowledge of 
what they are entitled to demand from their health services.

\section{Shared goals}

The fifth enabling factor is shared goals. Multisectoral collaboration is often understood as different sectors acting together to achieve outcomes that cannot be achieved by one sector alone, ${ }^{35}$ usually expressed in terms of shared interests. In this collaboration, however, the shared interests might seem less obvious, because ALIANMISAR has the role of monitoring a key stakeholder, the Ministry of Health. Key informants from health and other sectors reported that collaboration with ALIANMISAR has helped them to do their job better, achieve their goals, and, crucially, improve their own credibility. For example, in one health service, collaboration led to a change in communication style: the respectful behaviour by staff that had long been called for was finally achieved when it was formally recommended after an audit by ALIANMISAR. In another health service, a key informant said that the monitoring report produced by ALIANMISAR is a tool that can be used for follow-up with the Ministry of Health not only by ALIANMISAR but also by the health services. It provides them with documentation of the need for local resource allocation so that services and changes to facilities can be made to ensure culturally acceptable health services are available.

In terms of other sectors, the collaboration means that the local field officers of the ombudsman accompany ALIANMISAR monitors and can cover a wider geographical area in monitoring the right to health because the number of areas monitored is greater than they would cover alone. Furthermore, monitors from the ombudsman's office may not speak the language of the region where they work, so collaboration with women who speak the local language helps them to reach service users more effectively.

\section{Box 5: Constructive dialogue with health professionals about culturally appropriate} childbirth and delivery methods

\footnotetext{
To make childbirth practices and delivery methods in indigenous contexts more culturally appropriate, ALIANMISAR approached the medical and nursing schools of the State University, advocating that students be trained so that women can deliver in the position they find most comfortable. For example, vertical birth is a common cultural practice for Indigenous women. However, senior staff in the medical faculty were initially resistant. Volunteers had attended an exchange with Peru about their childbirth practices and ALIANMISAR subsequently returned to the university to discuss their findings with the medical faculty. Through this exchange, the university was motivated to implement a series of short training sessions on the topic to raise awareness among students completing supervised professional training in health services and plans to include these traditional methods in the school's training curriculum.
}

tionally, USAID funding provides for 30 municipalities and does not cover all those where ALIANMISAR is present. In municipalities without USAID funding, ALIANMISAR still conducts annual monitoring exercises, sometimes with financial support from other stakeholders such as the local municipality and the ombudsman.

Secondly, while the voluntary nature of Indigenous women's participation in ALIANMISAR gives credibility to their work, it also presents challenges, including a high turnover of volunteers. The collaboration and its successes is also dependent on unpaid work by Indigenous women, which is inconsistent with the principles of equity and gender equity. ${ }^{3738}$

These challenges do not detract from the collaboration's success nor from ALIANMISAR's achievements, but they do show that a strategic review of ALIANMISAR's collaborative work with the Ministry of Health, the ombudsman's office, and other stakeholders in improving the health and wellbeing of Guatemala's Indigenous women and their communities would be timely. As well as exploring how to fund ALIANMISAR in the long term it needs to include an evaluation of how it works, what it works on, and the outcomes and impacts for Indigenous women and communities.

\section{Conclusion}

Despite a commitment to formal mechanisms for civil society participation in governance post-1996 in Guatemala, Indigenous people, particularly Indigenous women, were not participating fully in those processes to effectively advocate for their interests and rights. ${ }^{1}$ 67 The creation of ALIANMISAR as an organisation run by Indigenous women for Indigenous women was an important response to this gap, both enabled by and resulting in more effective use of these participatory mechanisms.

We highlight the experience of, and challenges involved in, community led, multisectoral collaboration for improving the availability, accessibility, cultural acceptability, and quality of health services for Indigenous women. This experience shows what can be achieved in a low resource setting by an existing network of respected community volunteer advocates, with additional resources, capacity building, and a long term commitment to improving the health system. To produce long term improvements in Indigenous women's 


\section{lives, it is essential to continue building on ALIANMISAR's work and successes in a sustainable and equitable way. The findings from the review process will therefore be used to inform future efforts by ALIANMISAR.}

We acknowledge support from the following people and organisations, who made development of this case study possible: Sonia Son, ALIANMISAR secretariat; Herminia Reyes, chief of party

USAID/HEP+ Project; all key informants from the municipalities of Concepción Chiquirichapa, Chajul, and Chichicastenango, from REDMISAR, REDHOSEN, $\mathrm{HEP}+$ coordinators, the Ombudsman's Office, the health services, and the municipal government; all key stakeholders from other agencies at the national level including the Ombudsman's Office, the Ministry of Health and Social Assistance, Congress, SESAN, INCOPAS, Save the Children, and USAID. We thank al stakeholders for sharing their time and information.

Contributors and sources: SJS was supervisory author; DU, SJS, and CNV conceived the article outline; SJS and DU drafted and revised the first version with CNV and RGM; and SX and SP provided feedback and key inputs on drafts. For the case study review SJS and CNV wrote the draft working paper with inputs from other authors; CNV and RGM undertook key informant interviews; and CNV, RGM, SJS, and DU drafted an initial summary of findings used for consultation. All authors contributed intellectual content and approved the final version of this article for submission, with CNV serving as guarantor of the article.

Competing interests: We have read and understood BMJ policy on declaration of interests and have the following interests to declare: funding from the PMNCH Secretariat (SJS, DU, CNV, RGM) for consultancy fees and related costs for undertaking the case study; SX travel and daily costs for the consultation process and non-financial as national coordinator for ALIANMISAR; SP as an employee of the USAID/HEP+ project, which funds and manages ALIANMISAR; and organisational financial interests in the form of USAID funding to the HEP+ project for implementation of the ALIANMISAR initiative. The views expressed in this article are those of the authors and do not necessarily represent the views, decisions, or policies of the institutions with which they are affiliated.

Provenance and peer review: Commissioned; externally peer reviewed.

This article is part of a series proposed by the WHO Partnership for Maternal, Newborn and Child Health hosted by the World Health Organization (WHO PMNCH) and commissioned by The BMJ, which peer reviewed, edited, and made the decision to publish the article. Open access fees for the series are funded by WO-PMNCH.

Claudia Nieves Velásquez, independent consultant ${ }^{1}$

Maria del Rosario Garcia Meza, independent consultant $^{1}$

Daria Ukhova, independent consultant ${ }^{2}$

Silvia Xinico, national coordinator ${ }^{3}$

Susana Palma, senior civil society adviser ${ }^{4}$

Sarah Simpson, independent consultant ${ }^{5}$

${ }^{1}$ Guatemala City, Guatemala

\section{${ }^{2}$ Berlin, Germany}

${ }^{3}$ Alianza Nacional de Organizaciones de Mujeres Indigenas por la Salud Reproductiva Nutrición y Educación (ALIANMISAR), Guatemala City, Guatemala ${ }^{4}$ USAID Health Education and Policy Project,
Correspondence to: SXinico

silviaxinico@gmail.com

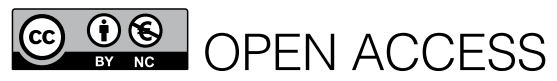

This is an Open Access article distributed under the terms of the Creative Commons Attribution IGO License (https://creativecommons.org/licenses/bync/3.0/igo/), which permits use, distribution, and reproduction for non-commercial purposes in any medium, provided the original work is properly cited.

\section{Check for updates}

1 Cerón A, Ruano AL, Sánchez S, et al. Abuse and discrimination towards Indigenous people in public health care facilities: experiences from rural Guatemala. Int J Equity Health 2016;15:77 doi:10.1186/s12939-016-0367-z

2 Anderson I, Robson B, Connolly M, et al. Indigenous and tribal peoples' health (The Lancet-Lowitja Institute Global Collaboration): a population study. Lancet 2016;388:131-57. doi:10.1016/S01406736(16)00345-7

3 Instituto Nacional de Estadística. Encuesta Nacional de Condiciones de Vida, Tomo I. INE, 2016.

4 van Dijk M, Ruiz MJ, Letona D, García SG. Ensuring intercultural maternal health care for Mayan women in Guatemala: a qualitative assessment. Cult Health Sex 2013;15(Suppl 3):S365-82.

5 Alianza Nacional de Organizaciones de Mujeres Indigenas por la Salud Reproductiva Nutrición y Educación(ALIANMISAR). Plan estratégico para la incidencia politica, 20162020. ALIANMISAR, 2016

6 Hernández A, Ruano AL, Marchal B, San Sebastián $M$, Flores $W$. Engaging with complexity to improve the health of Indigenous people: a call for the use of systems thinking to tackle health inequity. Int J Equity Health 2017;16:26. doi:10.1186/s12939-0170521-2

7 Cross H, De La Cruz M, Dent J. Government stewardship and primary health care in Guatemala since 1996.J Public Admin Dev 2018:1-12.

8 Kickbusch I, Hanefeld J. Role for academic institutions and think tanks in speeding progress on sustainable development goals. BM/ 2017;358:j3519. doi:10.1136/bmj.j3519

9 Pan American Health Organization. Guatemala. Health in the Americas, 2007 Volume II-Countries. 2007;II:374-93.

10 Ministerio de Salud Pública y Asistencia Social, Instituto Nacional de Estadística, Secretaría de Planificación y Programación de la Presidencia. VI Encuesta Nacional de Salud Materno Infantil 2014 2015. MSPAS and INE, 2016

11 Ministerio de Salud Pública y asistencia social Dirección General del SIAS Departamento de Epidemiología. Situación de la Mortalidad Materna en Guatemala, 2000- 2018. 2018. http:// epidemiologia.mspas.gob.gt/files/Publicaciones $\% 20$ 2018/MM/MM\%202000-2018.pdf

12 Secretaría de Planificación y Programación de la Presidencia. Ministerio de Salud Pública y Asistencia Social. Estudio Nacional de Mortalidad Materna 2007. Segeplan / MSPAS, 2011.

13 Ishida K, Stupp P, Turcios-Ruiz R, William DB, Espinoza E. Ethnic inequality in Guatemalan women's use of modern reproductive health care. Int Perspect Sex Reprod Health 2012;38:99-108. doi:10.1363/3809912

14 Avila C, Bright R, Gutierrez J, et al. Guatemala health system assessment. Health finance and governance project. Abt Associates Inc, 2015

15 Sheet F. Indigenous women's maternal health and maternal mortality. UNFPA, 2018. https://www.unfpa. org/resources/indigenous-womens-maternal-healthand-maternal-mortality

16 Bjorkman Nyqvist M, Svensson J, de Walque D. Community-based monitoring of primary healthcare providers in Uganda. 2017. https://www. povertyactionlab.org/evaluation/community-basedmonitoring-primary-healthcare-providers-uganda

17 United Nations. 61/295. United Nations declaration on the rights of Indigenous peoples. 2008. https:// www.un.org/esa/socdev/unpfii/documents/DRIPS_ en.pdf

18 Ministerio de Salud Pública y Asistencia Social Guatemala. Normas con Pertinencia Cultural, Hacia la Interculturalidad. Gobierno de Guatemala. 2011. http://www.mspas.gob.gt/ images/files/pueblosindigenas/documentos/ NormasPertinenciaCulturalenServiciosdeSalud.pdf

19 World Health Organization, International initiative for impact evaluation. An evidence map of social, behavioural and community engagement interventions for reproductive, maternal, newborn and child health. 2017. http://apps.who.int/iris/bitstream/hand le/10665/259399/9789240697263-eng. pdf?sequence $=1$

20 Office of the Ombudsman for Human Rights. Guatemala. 2018http://www.oacnudh.org.gt

21 Nutri-Salud final report 2017.. http://www.urc-chs. $\mathrm{com} /$ resources/community-nutrition-and-healthproject-nutri-salud-final-report

22 ALIANMISAR. Resultados del Monitoreo de la situación actual de las acciones de la Ventana de los Mil Días, en los servicios de salud del MSPAS.. 2017. Guatemala. http://www.alianmisar.org/userfiles/ Resultados\%20monitoreo\%20Ventana\%20de\%20 1000\%20d\%C3\%ADas\%20Agosto\%202017\%20 Final.pdf

23 Presentación monitoreo Ventana 1000D 2017 - ALIANMISAR. Guatemala City. (Jóvenes Artistas por la Justicia Social). https:// www.youtube.com/watch?v=BXfkamA8URk\&f eature=youtu.be++++https \%3A\%2F\%2Fyoutu. be\%2FsyyTXIvmtpl

24 ALIANMISAR. Mejoras que ha registrado la ALIANMISAR por procesos de abogacía, realizados después del monitoreo servicios de salud,2012-2018. Guatemala City: ALIANMISAR, 2018.http://www.alianmisar.org/userfiles/ SALUD\%20Registro\%20mejoras $\% 20$ a $\% 20$ nov $\% 20$ 2018(1).pdf

25 USAID/HEPP, Alianza Nacional de Organizaciones de Mujeres Indigenas por la Salud Reproductiva Nutrición y Educación(ALIANMISAR), OSAR, REDHOSEN. Compendio de leyes para la acción en salud reproductiva en Guatemala, 2014.. USAID/ HEPP, 2017. http://www.alianmisar.org/userfiles/ ALIANMISAR\%20Compendio\%20Legislativo\%20 2017(4).pdf

26 de la República C. Constitución Política de la República de Guatemala. Sección Séptima: Articulo 98: Participación de las comunidades en Programas de Salud. Congreso de la República, 1985.

27 Programa de las Naciones Unidas para Guatemala. Guatemala: hacia un Estado para el desarrollo humano. Informe nacional de desarrollo humano 2009/2010. PNUD, 2010:146-85.

28 de Guatemala G. Acuerdos de Paz. Acuerdo sobre aspectos socio-económicos y situación agraria: Inciso participación social en la sección sobre desarrollo social. Gobierno de Guatemala, 1996. https://www.sepaz.gob.gt/images/Descargas/ Acuerdos-de-Paz.pdf.

29 Martinez Ruiz C. A discussion with Andrea Santos, project coordinator, ALIANMISAR, Guatemala. 2016. https://berkleycenter.georgetown.edu/interviews/adiscussion-with-andrea-santos-project-coordinatoralianmisar-guatemala

30 Internacional del Trabajo O. Convenio Núm. 169 de la OIT sobre Pueblos Indigenas y Tribales. Declaración de las Naciones Unidas sobre los 
Derechos de los Pueblos Indígena. OIT/Oficina Regional para América Latina y el Caribe, 2014 http://www.ilo.org/wcmsp5/groups/public/--americas/---ro-lima/documents/publication/ wcms_345065.pdf.

31 USAID. Health and nutrition. Guatemala. USAID Health and Education Office, 2017. https://www.usaid.gov/ sites/default/files/documents/1862/Sector_BriefHealth_and_Nutrition_August_2017.pdf

32 Alianza Nacional de Organizaciones de Mujeres Indigenas por la Salud Reproductiva Nutrición y Educación(ALIANMISAR). Primera Encuesta sobre el trato durante la atención del parto en los servicios de salud del MSPAS. ALIANMISAR, 2015

33 ALIANMISAR. Vigilancia Ciudadana. ALIANMISAR, 2018. http://www.alianmisar.org/ node $/ 4$
34 Flores W, Ruano L. Empowering marginalized Indigenous communities through the monitoring of public health care services. New Delhi: Centre for health and social justice, COPASAH Global Secretariat; 2015. (COPASAH series on social accountability). Case study 6. https://www.copasah. net/uploads/1/2/6/4/12642634/cshj_-case study_6.pdf

35 World Health Organization. Glossary: Whole-of-government, whole-of-society, health in all policies, and multisectoral. WHO, 2016. http://www.who.int/global-coordinationmechanism/dialogues/glossary-whole-of-govtmultisectoral.pdf

36 Joshi A, McCluskey R. The art of 'bureaucraft': Why and how bureaucracies respond to citizen voice. Making all voices count research briefing. IDS, 2017.

37 World Health Organization. Working for health and growth: investing in the health workforce. Report of the High-Level Commission on Health Employment and Economic Growth..World Health Organization,

2016. http://apps.who.int/iris/bitstream/han dle/10665/250047/9789241511308-eng. pdf?sequence $=1$

38 Every woman every child. The global strategy for women's, children's and adolescents' health (20162030)

Supplement 1: Stakeholder information Supplement 2: Monitoring of health services by Indigenous women for Indigenous women

Supplement 3: Methods for the case study

Cite this as: BMJ 2018;363:k4677

http://dx.doi.org/10.1136/bmj.k4677 